\title{
Memprediksi Harga Komoditas Cabe Menggunakan Metode Backpropagation Di Wilayah Kota Payakumbuh
}

\author{
Allans Prima Aulia ${ }^{1}$, Yuhandri ${ }^{2}$, Fhajri Arye Gemilang ${ }^{1}$ \\ ${ }^{1}$ Universitas Fort De Kock Bukittinggi, Indonesia \\ ${ }^{2}$ Universitas Putra Indonesia YPTK Padang, Indonesia \\ allans1406@gmail.com, 2yuhandri.yunus@gmail.com, fhajri.gemilang@gmail.com
}

\begin{abstract}
Abstrak
Cabe merupakan salah satu bumbu dapur yang dibutuhkan mayoritas masyarakat Indonesia. Kebutuhan yang tinggi tersebut berdampak terhadap harga komoditas pertanian yang satu ini menjadi sangat fluktuatif. Penelitian ini menggunakan metode backpropagation untuk memprediksi harga komoditas cabe di Kota Payakumbuh dengan data bersumber dari BPS Kota Payakumbuh. Data yang digunakan adalah data harga cabe mingguan pada rentang waktu 2014 hingga 2019. Variabel data disusun ke bentuk time series dengan 4 nilai input dari masing-masing minggu per tahun, dan 1 nilai target. Dari hasil pengujian diperoleh nilai $M S E$ (Mean Squared Error) sebesar 0,00118 dengan akurasi prediksi sebesar 98,56\%. Hasil penelitian ini dapat membuktikan bahwa Jaringan Syaraf Tiruan menggunakan metode backpropagation dapat memprediksi harga komoditas cabe di Kota Payakumbuh dengan tingkat akurasi yang baik, sehingga dapat digunakan untuk tahun berikutnya.
\end{abstract}

Kata Kunci: Kecerdasan Buatan, Jaringan Syaraf Tiruan, Propagasi Balik, Prediksi Harga, Prediksi Cabe.

\begin{abstract}
-
Chili is one of the spices needed by the majority of Indonesian people. These high needs have an impact on the price of this agricultural commodity which has become very fluctuated. This study, uses the backpropagation method to predict chilli prices in Payakumbuh City, with data sourced from the Badan Pusat Statistik Kota Payakumbuh. The data format are weekly chilli price data for the period 2014 to 2019. Data variables are arranged into time series forms with 4 input values from each week per year, and 1 target value. From the test results obtained the MSE value (Mean Squared Error) of 0.00118 with prediction accuracy of $98.56 \%$. The results of this study can prove that Artificial Neural Networks using the backpropagation method can predict commodity prices for chilli in Payakumbuh City with a good level of accuracy, so that it can be used for the following year.
\end{abstract}

Keywords: Artificial Intelligence, Artificial Neural Networks, Reverse Propagation, Price Prediction, Chili Prediction.

\section{PENDAHULUAN}

Teknologi informasi telah mengambil peran penting dalam kehidupan manusia. Hampir seluruh sendi kehidupan manusia dewasa ini telah melibatkan teknologi informasi. Salah satu produk teknologi informasi yang lazim digunakan manusia adalah sistem informasi. Sistem informasi membantu manusia dalam mendapatkan informasi sebagai acuan untuk mengambil keputusan.Sebab kebutuhan manusia yang tinggi akan sebuah informasi, sistem informasi pun berkembang cepat. Menyesuaikan kebutuhan dan harapan dari manusia sebagai penggunanya. Sajian-sajian informasi dapat berupa data-data prediksi yang akan membantu user dalam mengambil keputusan. Salah satu contohnya adalah sistem informasi prediksi cuaca yang telah memberi banyak manfaat pada manusia. Begitu pula dengan sistem prediksi harga saham yang memberi andil besar pada pelaku perdagangan.Di sisi lain, cabe merupakan salah satu bumbu dapur yang dibutuhkan mayoritas masyarakat Indonesia. Kebutuhan yang tinggi tersebut berdampak terhadap harga komoditas pertanian yang satu ini menjadi sangat fluktuatif. Fluktuasi harga komoditas cabe di Indonesia kerap berdampak bagi inflasi. Kondisi ini tak selalu memberi efek yang baik bagi petani maupun pembeli. Ketika harga cabe terlalu rendah, petani akan mengalami kerugian, sebaliknya ketika harga terlalu mahal maka pembeli dirugikan.Permasalahan fluktuasi harga komoditas cabe tentu tidak lepas dari hukum pasar, yakni supply and demand. Ketika permintaan tinggi sementara ketersediaan barang rendah maka harga akan mahal, begitupun sebaliknya ketika permintaan rendah dan ketersediaan barang tinggi maka harga akan murah. Karenanya,pemerataan supply terhadap 
demand menjadi suatu kebutuhan untuk stabilitas harga di pasaran.

Permasalahan gap antara permintaan dan ketersediaan barang ini tentunya dapat dipelajari dengan data-data pasar di masa lampau. Dari sajian data tersebut dapat dipelajari tentang faktor-faktor yang menyebabkan pasokan cabe tinggi maupun rendah. Begitu pula dengan grafik permintaan yang dapat dipelajari pola serta penyebab perubahannya. Sehingga selanjutnya diharapkan didapat sebuah metode penyelesaian untuk kestabilan permintaan serta ketersediaan cabe, yang kemudian akan berdampak pada stabilitas harga.Metode backpropagation dapat digunakan untuk mempelajari pola penyebaran penyakit Demam Berdarah Dengue (DBD) di kota Ambon. Dari 82 data yang digunakan, 62 data digunakan untuk pelatihan sementara 20 data dipakai sebagai data testing. Data yang dipakai adalah data Demam Berdarah Dengue (DBD) periode 2011-2015 di kota Ambon. Hasil penelitian memperoleh akurasi sebesar 90\%, arsitektur jaringan terbaik dari satu hidden layer denganjumlah neuron sebanyak 25 neuron dan algoritma pelatihan terbaik yaitu dengan menggunakan learning rate sebesar 0,4 dengan MSE 0,0099 (Lesnussa, Sinay and Idah, 2017)

Backpropagation mendapatkan akurasi sebesar 91,72\% pada kasus klasifikasi suara jantung. Penelitian ini menggunakan input data berupa file suara jantung berformat .MP3 dari $w e b$, masing-masing file berbeda ukuran dan durasi suaranya. Dari data file suara jantung tersebut, metode backpropagation terbukti mampu mengklasifikasi dengan baik kondisi jantung normal dan abnormal (Nur Hudha Wijaya, Indah Soesanti, 2017). Prediksi volume produksi minyak sawit nasional dengan backpropagation memperoleh akurasi yang sangat baik, yakni 99,98\%. Data yang digunakan merupakan data historikal produksi sawit nasional
Page : 33-48

periode tahun 1967-2015 yang bersumber dari Ditjenbun, serta data USDA tahun 2016. Dari data historikal tersebut kemudian ditentukan nilai minimum, maksimum, rata-rata, median, dan nilai akhir untuk pemodelan pola perubahan volume produksi sawit nasional (Pamungkas et al., 2018). Metode backpropagation mendapatkan akurasi 99\% untuk prediksi penerima beasiswa. Data yang digunakan pada penelitian bersumber dari Universitas Amikom Yogyakarta. Dari keseluruhan 3.000 dataset yang digunakan, 2.250 dipakai untuk data training, dan 750 dataset lainnya untuk data testing. Nilai error terendah diperoleh sebesar 0,0001 pada epoch 329 dengan menggunakan learning rate sebesar 0,2 dan momentum 0,2 serta konfigurasi hidden layer sebanyak satu layer, jumlah neuron 25 buah (Pujianto, Kusrini and Sunyoto, 2018).

Algoritma backpropagation memperoleh akurasi 97,92\% untuk memprediksi harga komoditi pangan di Kota Palu. Data yang digunakan bersumber dari Dinas Pertanian Provinsi Sulawesi Tengah. Dalam laporan penelitian ini diprediksi fluktuasi harga kebutuhan pokok pada tahun 2016 berdasarkan data tahun 2015. Prediksi fluktuasi dibuat per bulan dimana rentang waktu januari-maret diperoleh akurasi sebesar $97,41 \%$, sedangkan periode januaridesember diperoleh akurasi 97,92\% (Peole, Ratianingsih and Lusiyanti, 2018).

\section{METODOLOGI PENELITIAN}

Sistematika tahapan penelitian akan membimbing peneliti agar tetap terukur dan terarah dalam melaksanakan kegiatan penelitian sehingga tujuan yang telah ditetapkan dapat dicapai. Dalam penelitian "Prediksi Harga Komoditas Cabe Menggunakan Algoritma Backpropagation pada Wilayah Kota Payakumbuh" ini, kerangka kerja yang disiapkan digambarkan pada gambar 1 .

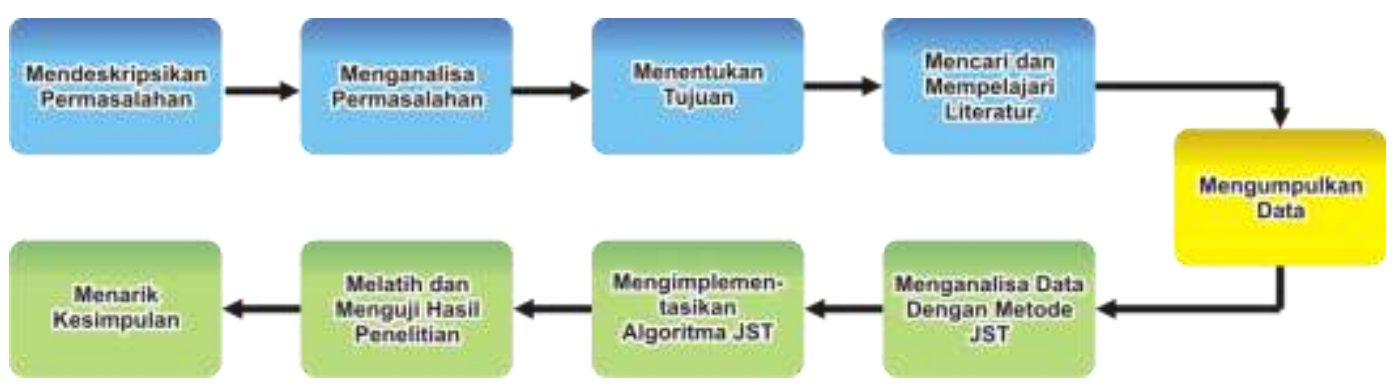

Gambar 1 : Kerangka Kerja Penelitian 
Berdasarkan kerangka kerja penelitian pada gambar 3.1, dapat diuraikan tahapan-tahapan penelitian sebagai berikut :

\section{Mendeskripsikan permasalahan}

Permasalahan yang penulis temukan dideskripsikan secara jelas sehingga akan terlihat pokok dari masalah tersebut. Bagian ini merupakan tahapan mendasar yang menentukan untuk tahapan-tahapan selanjutnya. Di dalam deskripsi masalah ini juga ditentukan batasan masalah serta ruang lingkup yang menjadi objek penelitian. Penentuan batasan masalah dan ruang lingkup ditujukan untuk memfokuskan penelitian pada batasan yang ditetapkan.

2. Menganalisa permasalahan

$$
\text { Setelah masalah dideskripsikan, }
$$
selanjutnya dilakukan analisis terhadap permasalahan tersebut. Langkah analisis ini bertujuan untuk benar-benar memahami permasalahan yang telah ditetapkan batasan dan ruang lingkupnya pada tahap awal. Analisis dan pemahaman yang baik terhadap permasalahan akan mempengaruhi solusi yang dihasilkan.

\section{Menentukan tujuan}

Setelah menganalisa permasalahan, diperoleh sebuah pemahaman terhadap permasalahan yang ada. Menentukan tujuan dimaksudkan agar solusi yang hendak dicapai ditentukan dengan jelas dan terukur. Solusi tersebut diharapkan benar-benar bisa menyelesaikan permasalahan yang ada.

4. Mencari dan mempelajari literatur

Untuk mencapai tujuan yang telah ditetapkan, selanjutnya dicari literatur-literatur yang berhubungan sehingga dapat digunakan. Kemudian literatur-literatur tersebut dipelajari untuk menemukan keterkaitannya dengan permasalahan yang ditemukan. Literatur-literatur yang memiliki keterkaitan akan dipakai untuk membantu peneliti dalam mencapai tujuan penelitian.

Literatur bersumber dari perpustakaan Universitas Putra Indonesia "YPTK" padang, berupa laporan penelitian JST dengan metode backpropagation. Literatur lainnya berupa bukubuku JST metode backpropagation dan jurnaljurnal dari website (internet). Sumber-sumber tersebut digunakan dengan mempertimbangkan relevansi permasalahan serta kredibilitas sumber yang akan dimuat dalam laporan penelitian ini.

5. Pengumpulan data

Pengumpulan data bertujuan untuk data pelatihan (training) dan data pengujian (testing) dalam implementasi metode backpropagation. Dalam JST dengan metode backpropagation, jumlah data yang dapat dikumpulkan akan berdampak signifikan terhadap output yang dihasilkan. Semakin banyak data yang dikumpulkan maka akan semakin baik pula JST mempelajari dan menyelesaikan permasalahan yang ada.

Data yang dikumpulkan berupa data akurat yang selanjutnya dibagi menjadi set data pelatihan dan set data pengujian. Set data pelatihan digunakan untuk melatih jaringan, sementara set data pengujian digunakan setelah set pelatihan selesai. Set data pengujian ini akan menunjukkan hasil kemampuan JST memecahkan permasalahan yang belum dipelajari ketika input dimasukkan.

6. Menganalisa data dengan metode JST

Tahapan ini bertujuan untuk menganalisis dan memahami teknik prediksi yang akan digunakan pada data yang telah terkumpul. Analisis meliputi pemahaman terhadap nilai input, proses dan output yang diharapkan. Pada tahapan ini juga ditentukan arsitektur JST yang dipakai, serta algoritma pelatihan yang akan digunakan untuk set training JST.

7. Mengimplementasikan algoritma JST Setelah analisis analisis data dilakukan, tahapan selanjutnya adalah mengimplementasikan algoritma JST. Implementasi algoritma JST sesuai dengan arsitektur jaringan serta algortima pelatihan yang telah ditentukan pada tahap sebelumnya. Implementasi algoritma JST secara umum dilakukan dengan tahapan-tahapan utama sebagai berikut :
a. Pengambilan input
b. Penelusuran error
c. Penyesuaian bobot

8. Melatih dan menguji hasil penelitian

Tahapan melatih dan menguji hasil penelitian ini akan menunjukkan nilai akurasi prediksi yang dihasilkan oleh sistem. Data yang telah dikumpulkan pada tahap sebelumnya dilatih sesuai algoritma training yang dipilih, kemudian dilakukan pengujian prediksi. Pengujian prediksi menggunakan metode backpropagation untuk data sampel yang telah ada.

Langkah-langkah yang dilakukan pada tahapan pengujian adalah sebagai berikut :

a. Pengolahan data secara manual menggunakan algoritma backpropagation.

b. Data yang sama dengan tahap (a) selanjutnya diuji dengan komputerisasi menggunakan software Matlab R2011b, dengan algoritma backpropagation.

c. Membandingakan hasil pengujian yang didapat secara manual dengan 
hasil pengujian dengan Matlab R2011b.

d. Menguji hasil pengolahan data secara komputerisasi pada Matlab R2011b dengan data yang lebih lengkap menggunakan beberapa model jaringan.

9. Menarik kesimpulan

Tahapan terakhir dalam kerangka kerja penelitian ini adalah menarik kesimpulan. Penarikan kesimpulan didasarkan pada studi pustaka, pembahasan permasalahan analisis hasil penelitian. Kesimpulan yang diperoleh berupa nilai prediksi harga komoditas cabe di wilayah Kota Payakumbuh. Dari nilai prediksi ini dapat diketahui tingkat akurasi prediksi menggunakan JST dengan algoritma backpropagation.

\section{ANALISA DAN HASIL}

Pada penelitian ini, digunakan data harga komoditas cabe di Kota Payakumbuh pada
Page : 33-48

rentang waktu 2014 hingga 2018 yang bersumber dari Badan Pusat Statistik (BPS) Kota Payakumbuh. Proses pengambilan data dilakukan dengan mengirimkan surat permohonan permintaan data untuk penelitian ke BPS Kota Payakumbuh, selanjutnya data diberikan dalam format .xlsx. Sajian data yang termuat dalam dokumen spreadsheet dari BPS Kota Payakumbuh berupa rekap harga mingguan komoditas cabe di Kota Payakumbuh.

Jumlah data yang akan digunakan dalam penelitian ini adalah 265 data harga komoditas cabe dalam sajian per minggu. Dari sumbernya, data BPS terdiri dari 21 item harga komoditas yang disajikan per minggu. Karena dalam penelitian ini penulis hanya melakukan prediksi pada komoditas cabe, maka diambil 1 item saja yaitu cabe keriting kampung.

Berikut ini adalah data harga komoditas cabe di Kota Payakumbuh pada tahun 2014, yang akan menjadi input pertama ( $x l$ ) pada sistem prediksi :

Tabel 1 Data Harga Cabe Tahun 2014

\begin{tabular}{llccccc}
\hline No Bulan & Minggu ke- & $\begin{array}{c}\text { Harga } \\
(\mathrm{Rp} / \mathrm{Kg})\end{array}$ & No & Bulan & Minggu ke & $\begin{array}{c}\text { Harga } \\
(\mathrm{Rp} / \mathrm{Kg})\end{array}$
\end{tabular}

\begin{tabular}{|c|c|c|c|c|c|c|c|}
\hline 1 & Januari & 1 & 40000 & 28 & Juli & 2 & 14000 \\
\hline 2 & & 2 & 42000 & 29 & & 3 & 16000 \\
\hline 3 & & 3 & 46000 & 30 & & 4 & 14000 \\
\hline 4 & & 4 & 28000 & 31 & & 5 & 14000 \\
\hline 5 & & 5 & 40000 & 32 & Agustus & 1 & 18000 \\
\hline 6 & Februari & 1 & 36000 & 33 & & 2 & 18000 \\
\hline 7 & & 2 & 34000 & 34 & & 3 & 22000 \\
\hline 8 & & 3 & 28000 & 35 & & 4 & 24000 \\
\hline 9 & & 4 & 26000 & 36 & September & 1 & 22000 \\
\hline 10 & Maret & 1 & 26000 & 37 & & 2 & 28000 \\
\hline 11 & & 2 & 24000 & 38 & & 3 & 36000 \\
\hline 12 & & 3 & 24000 & 39 & & 4 & 44000 \\
\hline 13 & & 4 & 20000 & 40 & & 5 & 55000 \\
\hline 14 & April & 1 & 18000 & 41 & Oktober & 1 & 56000 \\
\hline 15 & & 2 & 17000 & 42 & & 2 & 43000 \\
\hline 16 & & 3 & 17000 & 43 & & 3 & 48000 \\
\hline 17 & & 4 & 16000 & 44 & & 4 & 40000 \\
\hline 18 & & 5 & 20000 & 45 & November & 1 & 42000 \\
\hline 19 & Mei & 1 & 20000 & 46 & & 2 & 56000 \\
\hline 20 & & 2 & 20000 & 47 & & 3 & 44000 \\
\hline 21 & & 3 & 14000 & 48 & & 4 & 56000 \\
\hline 22 & & 4 & 16000 & 49 & Desember & 1 & 44000 \\
\hline 23 & Juni & 1 & 16000 & 50 & & 2 & 44000 \\
\hline 24 & & 2 & 13000 & 51 & & 3 & 36000 \\
\hline 25 & & 3 & 14000 & 52 & & 4 & 44000 \\
\hline 26 & & 4 & 14000 & 53 & & 5 & 44000 \\
\hline
\end{tabular}


Di bawah ini adalah data harga komoditas cabe di Kota Payakumbuh pada tahun 2015 dengan sumber data BPS Kota
Payakumbuh, yang akan menjadi input kedua $(x 2)$ pada sistem prediksi, ditunjukkan pada tabel 2 .

Tabel 2 Data Harga Cabe Tahun 2015

No Bulan $\quad$ Minggu ke- $\quad \begin{gathered}\text { Harga } \\ (\mathrm{Rp} / \mathrm{Kg})\end{gathered} \quad$ No $\quad$ Bulan $\quad$ Minggu ke- $\quad \begin{gathered}\text { Harga } \\ (\mathrm{Rp} / \mathrm{Kg})\end{gathered}$

\begin{tabular}{|c|c|c|c|c|c|c|c|}
\hline 1 & \multirow[t]{5}{*}{ Januari } & 1 & 60000 & 28 & \multirow[t]{4}{*}{ Juli } & 1 & 30000 \\
\hline 2 & & 2 & 45000 & 29 & & 2 & 46000 \\
\hline 3 & & 3 & 35000 & 30 & & 3 & 40000 \\
\hline 4 & & 4 & 30000 & 31 & & 4 & 32000 \\
\hline 5 & & 5 & 28000 & 32 & \multirow[t]{4}{*}{ Agustus } & 1 & 40000 \\
\hline 6 & \multirow[t]{4}{*}{ Februari } & 1 & 28000 & 33 & & 2 & 46000 \\
\hline 7 & & 2 & 26000 & 34 & & 3 & 40000 \\
\hline 8 & & 3 & 28000 & 35 & & 4 & 36000 \\
\hline 9 & & 4 & 28000 & 36 & \multirow[t]{5}{*}{ September } & 1 & 34000 \\
\hline 10 & \multirow[t]{5}{*}{ Maret } & 1 & 18000 & 37 & & 2 & 36000 \\
\hline 11 & & 2 & 26000 & 38 & & 3 & 36000 \\
\hline 12 & & 3 & 20000 & 39 & & 4 & 38000 \\
\hline 13 & & 4 & 20000 & 40 & & 5 & 32000 \\
\hline 14 & & 5 & 21000 & 41 & \multirow[t]{4}{*}{ Oktober } & 1 & 30000 \\
\hline 15 & \multirow[t]{4}{*}{ April } & 1 & 22000 & 42 & & 2 & 32000 \\
\hline 16 & & 2 & 24000 & 43 & & 3 & 25000 \\
\hline 17 & & 3 & 24000 & 44 & & 4 & 60000 \\
\hline 18 & & 4 & 25000 & 45 & \multirow[t]{4}{*}{ November } & 1 & 45000 \\
\hline 19 & \multirow[t]{4}{*}{ Mei } & 1 & 28000 & 46 & & 2 & 30000 \\
\hline 20 & & 2 & 28000 & 47 & & 3 & 38000 \\
\hline 21 & & 3 & 28000 & 48 & & 4 & 30000 \\
\hline 22 & & 4 & 28000 & 49 & \multirow[t]{5}{*}{ Desember } & 1 & 38000 \\
\hline 23 & \multirow[t]{5}{*}{ Juni } & 1 & 28000 & 50 & & 2 & 38000 \\
\hline 24 & & 2 & 32000 & 51 & & 3 & 36000 \\
\hline 25 & & 3 & 44000 & 52 & & 4 & 38000 \\
\hline 26 & & 4 & 40000 & 53 & & 5 & 38000 \\
\hline 27 & & 5 & 28000 & & ah Minggu & 53 & \\
\hline
\end{tabular}

Di bawah ini adalah data harga komoditas cabe di Kota Payakumbuh pada tahun 2016 dengan sumber data BPS Kota
Payakumbuh, yang akan menjadi input ketiga $(x 3)$ pada sistem prediksi, ditunjukkan pada tabel 3. 
Tabel 3 Data Harga Cabe Tahun 2016

No Bulan Minggu ke- $\begin{gathered}\text { Harga } \\ (\mathrm{Rp} / \mathrm{Kg})\end{gathered} \quad$ No $\quad$ Bulan $\quad$ Minggu ke- $\quad \begin{gathered}\text { Harga } \\ (\mathrm{Rp} / \mathrm{Kg})\end{gathered}$

\begin{tabular}{|c|c|c|c|c|c|c|c|}
\hline 1 & Januari & 1 & 49000 & 28 & Juli & 2 & 26000 \\
\hline 2 & & 2 & 45000 & 29 & & 3 & 30000 \\
\hline 3 & & 3 & 32000 & 30 & & 4 & 28000 \\
\hline 4 & & 4 & 30000 & 31 & & 5 & 32000 \\
\hline 5 & Februari & 1 & 30000 & 32 & Agustus & 1 & 29000 \\
\hline 6 & & 2 & 32000 & 33 & & 2 & 46000 \\
\hline 7 & & 3 & 44000 & 34 & & 3 & 40000 \\
\hline 8 & & 4 & 40000 & 35 & & 4 & 36000 \\
\hline 9 & Maret & 1 & 44000 & 36 & September & 1 & 34000 \\
\hline 10 & & 2 & 48000 & 37 & & 2 & 36000 \\
\hline 11 & & 3 & 54000 & 38 & & 3 & 36000 \\
\hline 12 & & 4 & 36000 & 39 & & 4 & 38000 \\
\hline 13 & & 5 & 34000 & 40 & & 5 & 32000 \\
\hline 14 & April & 1 & 32000 & 41 & Oktober & 1 & 30000 \\
\hline 15 & & 2 & 28000 & 42 & & 2 & 32000 \\
\hline 16 & & 3 & 24000 & 43 & & 3 & 25000 \\
\hline 17 & & 4 & 24000 & 44 & & 4 & 49000 \\
\hline 18 & Mei & 1 & 30000 & 45 & November & 1 & 45000 \\
\hline 19 & & 2 & 28000 & 46 & & 2 & 30000 \\
\hline 20 & & 3 & 26000 & 47 & & 3 & 38000 \\
\hline 21 & & 4 & 25000 & 48 & & 4 & 30000 \\
\hline 22 & & 5 & 24000 & 49 & Desember & 1 & 38000 \\
\hline 23 & Juni & 1 & 24000 & 50 & & 2 & 38000 \\
\hline 24 & & 2 & 20000 & 51 & & 3 & 36000 \\
\hline 25 & & 3 & 22000 & 52 & & 4 & 38000 \\
\hline 26 & & 4 & 26000 & 53 & & 5 & 38000 \\
\hline 27 & Juli & 1 & 25000 & \multicolumn{2}{|c|}{ Jumlah Minggu } & 53 & \\
\hline
\end{tabular}

Di bawah ini adalah data harga komoditas cabe di Kota Payakumbuh pada tahun 2017 dengan sumber data BPS Kota
Payakumbuh, yang akan menjadi input keempat (x4) pada sistem prediksi, ditunjukkan pada tabel 4.

Tabel 4 Data Harga Cabe Tahun 2017

No Bulan $\begin{array}{cccccc}\begin{array}{c}\text { Minggu } \\ \text { ke- }\end{array} & \begin{array}{c}\text { Harga } \\ (\mathrm{Rp} / \mathrm{Kg})\end{array} & \text { No } & \text { Bulan } & \begin{array}{c}\text { Minggu } \\ \text { ke- }\end{array} & \begin{array}{c}\text { Harga } \\ (\mathrm{Rp} / \mathrm{Kg})\end{array}\end{array}$

\begin{tabular}{|c|c|c|c|c|c|c|c|}
\hline 1 & Januari & 1 & 45000 & 28 & Jul & 1 & 18000 \\
\hline 2 & & 2 & 52000 & 29 & & 2 & 26000 \\
\hline
\end{tabular}


Jurnal KomtekInfo, Vol.8 No.1 Tahun 2021

e-ISSN : 2502-8758 || p-ISSN : 2356-0010

DOI : $10.35134 /$ komtekinfo.v7i4

\begin{tabular}{|c|c|c|c|c|c|c|c|}
\hline & & & & & & & \\
\hline 3 & & 3 & 34000 & 30 & & 3 & 22000 \\
\hline 4 & & 4 & 36000 & 31 & & 4 & 26000 \\
\hline 5 & & 5 & 46000 & 32 & Agustus & 1 & 26000 \\
\hline 6 & Februari & 1 & 35000 & 33 & & 2 & 28000 \\
\hline 7 & & 2 & 20000 & 34 & & 3 & 24000 \\
\hline 8 & & 3 & 26000 & 35 & & 4 & 32000 \\
\hline 9 & & 4 & 30000 & 36 & & 5 & 36000 \\
\hline 10 & Maret & 1 & 30000 & 37 & September & 1 & 34000 \\
\hline 11 & & 2 & 26000 & 38 & & 2 & 26000 \\
\hline 12 & & 3 & 20000 & 39 & & 3 & 38000 \\
\hline 13 & & 4 & 20000 & 40 & & 4 & 30000 \\
\hline 14 & April & 1 & 20000 & 41 & Oktober & 1 & 44000 \\
\hline 15 & & 2 & 20000 & 42 & & 2 & 50000 \\
\hline 16 & & 3 & 20000 & 43 & & 3 & 40000 \\
\hline 17 & & 4 & 20000 & 44 & & 4 & 45000 \\
\hline 18 & Mai & 1 & 20000 & 45 & & 5 & 52000 \\
\hline 19 & & 2 & 26000 & 46 & November & 1 & 44000 \\
\hline 20 & & 3 & 22000 & 47 & & 2 & 38000 \\
\hline 21 & & 4 & 20000 & 48 & & 3 & 44000 \\
\hline 22 & & 5 & 16000 & 49 & & 4 & 38000 \\
\hline 23 & Juni & 1 & 16000 & 50 & Desember & 1 & 38000 \\
\hline 24 & & 2 & 18000 & 51 & & 2 & 26000 \\
\hline 25 & & 3 & 24000 & 52 & & 3 & 38000 \\
\hline 26 & & 4 & 24000 & 53 & & 4 & 38000 \\
\hline 27 & & 5 & 24000 & & ah Minggu & 53 & \\
\hline
\end{tabular}

Di bawah ini adalah data harga komoditas cabe di Kota Payakumbuh pada tahun 2018 dengan sumber data BPS Kota
Payakumbuh, yang akan menjadi target output $(T)$ pada sistem prediksi, ditunjukkan pada tabel 5.

Tabel 5 Data Harga Cabe Tahun 2018

\begin{tabular}{lcccccc}
\hline No Bulan & $\begin{array}{c}\text { Minggu } \\
\text { ke- }\end{array}$ & $\begin{array}{c}\text { Harga } \\
(\mathrm{Rp} / \mathrm{Kg})\end{array}$ & No & Bulan & $\begin{array}{c}\text { Minggu } \\
\text { ke- }\end{array}$ & $\begin{array}{c}\text { Harga } \\
(\mathrm{Rp} / \mathrm{Kg})\end{array}$
\end{tabular}

\begin{tabular}{|c|c|c|c|c|c|c|c|}
\hline 1 & \multirow[t]{5}{*}{ Januari } & 1 & 52000 & 28 & \multirow[t]{4}{*}{ Juli } & 2 & 32000 \\
\hline 2 & & 2 & 50000 & 29 & & 3 & 32000 \\
\hline 3 & & 3 & 51000 & 30 & & 4 & 28000 \\
\hline 4 & & 4 & 50000 & 31 & & 5 & 28000 \\
\hline 5 & & 5 & 50000 & 32 & \multirow[t]{4}{*}{ Agustus } & 1 & 36000 \\
\hline 6 & \multirow[t]{3}{*}{ Februari } & 1 & 36000 & 33 & & 2 & 36000 \\
\hline 7 & & 2 & 36000 & 34 & & 3 & 30000 \\
\hline 8 & & 3 & 46000 & 35 & & 4 & 24000 \\
\hline
\end{tabular}




\begin{tabular}{|c|c|c|c|c|c|c|c|}
\hline 9 & & 4 & 44000 & 36 & September & 1 & 30000 \\
\hline 10 & \multirow[t]{4}{*}{ Maret } & 1 & 46000 & 37 & & 2 & 28000 \\
\hline 11 & & 2 & 52000 & 38 & & 3 & 28000 \\
\hline 12 & & 3 & 44000 & 39 & & 4 & 35000 \\
\hline 13 & & 4 & 40000 & 40 & Oktober & 1 & 36000 \\
\hline 14 & \multirow[t]{4}{*}{ April } & 1 & 46000 & 41 & & 2 & 40000 \\
\hline 15 & & 2 & 40000 & 42 & & 3 & 46000 \\
\hline 16 & & 3 & 40000 & 43 & & 4 & 50000 \\
\hline 17 & & 4 & 36000 & 44 & & 5 & 52000 \\
\hline 18 & \multirow[t]{5}{*}{ Mei } & 1 & 36000 & 45 & November & 1 & 50000 \\
\hline 19 & & 2 & 32000 & 46 & & 2 & 42000 \\
\hline 20 & & 3 & 32000 & 47 & & 3 & 34000 \\
\hline 21 & & 4 & 25000 & 48 & & 4 & 42000 \\
\hline 22 & & 5 & 24000 & 49 & Desember & 1 & 35000 \\
\hline 23 & \multirow[t]{4}{*}{ Juni } & 1 & 24000 & 50 & & 2 & 35000 \\
\hline 24 & & 2 & 26000 & 51 & & 3 & 30000 \\
\hline 25 & & 3 & 26000 & 52 & & 4 & 35000 \\
\hline 26 & & 4 & 26000 & 53 & & 5 & 35000 \\
\hline 27 & Juli & 1 & 30000 & & ah Minggu & 53 & \\
\hline
\end{tabular}

Pada sistem prediksi harga komoditas cabe menggunakan metode backpropagation ini, digunakan fungsi aktivasi sigmoid biner yang sejatinya tidak pernah mencapai angka 0 s.d. 1 . Oleh karena itu, pada data harga komoditas cabe yang diperoleh dari BPS Kota Payakumbuh perlu dilakukan normalisasi untuk dapat diterapkan pada sistem prediksi menggunakan metode backpropagation. Proses normalisasi data harga dilakukan dengan mengubah data-data harga tersebut menjadi range 0,1 s.d. 0,9 dengan menggunakan persamaan sebagai berikut :

$$
X^{\prime}=\frac{0,8(x-a)}{b-a}+0,1
$$

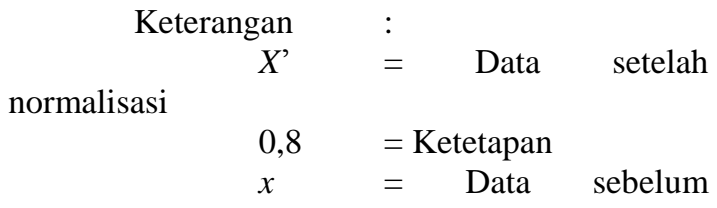

normalisasi (data asli) tertinggi

$a \quad=$ Nilai data input asli

terendah

$b \quad=$ Nilai data input asli

Untuk memudahkan proses normalisasi data yang akan digunakan pada tahap pelatihan jaringan maupun pengujian jaringan, maka data asli yang terpisah per tahun digabung menjadi satu tabel. Setelahnya, masing-masing input akan ditentukan nilai tertinggi dan terendahnya ( $a$ dan $b$ ) untuk proses normalisasi data. Dari 53 minggu data yang ada, data harga cabe sebanyak 43 minggu akan digunakan dalam proses pelatihan jaringan, sementara 10 data lainnya akan digunakan sebagai data pengujian.Dari proses perhitungan terhadap semua data harga cabe per minggu di Kota Payakumbuh dengan total data harga cabe sebanyak 53 data, maka diperoleh hasil data harga cabe setelah normalisasi seperti dimuat dalam tabel 7 berikut ini :

Tabel 6 Data Pelatihan dan Pengujian Setelah Normalisasi DATA PELATIHAN (TRAINING DATA)

\begin{tabular}{cccccc}
\hline Minggu ke- & x1 (2014) & x2(2015) & x3 (2016) & x4 (2017) & T (2018) \\
& & & & & \\
\hline 1 & 0,4224 & 0,9000 & 0,6800 & 0,6800 & 0,9000 \\
\hline
\end{tabular}


Jurnal KomtekInfo , Vol.8 No.1 Tahun 2021 e-ISSN : 2502-8758 || p-ISSN : 2356-0010 DOI : $10.35134 /$ komtekinfo.v7i4

\begin{tabular}{|c|c|c|c|c|c|}
\hline 2 & 0,4463 & 0,6143 & 0,6000 & 0,8200 & 0,8429 \\
\hline 3 & 0,4940 & 0,4238 & 0,3400 & 0,4600 & 0,8714 \\
\hline 4 & 0,2791 & 0,3286 & 0,3000 & 0,5000 & 0,8429 \\
\hline 5 & 0,4224 & 0,2905 & 0,3000 & 0,7000 & 0,8429 \\
\hline 6 & 0,3746 & 0,2905 & 0,3400 & 0,4800 & 0,4429 \\
\hline 7 & 0,3507 & 0,2524 & 0,5800 & 0,1800 & 0,4429 \\
\hline 8 & 0,2791 & 0,2905 & 0,5000 & 0,3000 & 0,7286 \\
\hline 9 & 0,2552 & 0,2905 & 0,5800 & 0,3800 & 0,6714 \\
\hline 10 & 0,2552 & 0,1000 & 0,6600 & 0,3800 & 0,7286 \\
\hline 11 & 0,2313 & 0,2524 & 0,7800 & 0,3000 & 0,9000 \\
\hline 12 & 0,2313 & 0,1381 & 0,4200 & 0,1800 & 0,6714 \\
\hline 13 & 0,1836 & 0,1381 & 0,3800 & 0,1800 & 0,5571 \\
\hline 14 & 0,1597 & 0,1571 & 0,3400 & 0,1800 & 0,7286 \\
\hline 15 & 0,1478 & 0,1762 & 0,2600 & 0,1800 & 0,5571 \\
\hline 16 & 0,1478 & 0,2143 & 0,1800 & 0,1800 & 0,5571 \\
\hline 17 & 0,1358 & 0,2143 & 0,1800 & 0,1800 & 0,4429 \\
\hline 18 & 0,1836 & 0,2333 & 0,3000 & 0,1800 & 0,4429 \\
\hline 19 & 0,1836 & 0,2905 & 0,2600 & 0,3000 & 0,3286 \\
\hline 20 & 0,1836 & 0,2905 & 0,2200 & 0,2200 & 0,3286 \\
\hline 21 & 0,1119 & 0,2905 & 0,2000 & 0,1800 & 0,1286 \\
\hline 22 & 0,1358 & 0,2905 & 0,1800 & 0,1000 & 0,1000 \\
\hline 23 & 0,1358 & 0,2905 & 0,1800 & 0,1000 & 0,1000 \\
\hline 24 & 0,1000 & 0,3667 & 0,1000 & 0,1400 & 0,1571 \\
\hline 25 & 0,1119 & 0,5952 & 0,1400 & 0,2600 & 0,1571 \\
\hline 26 & 0,1119 & 0,5190 & 0,2200 & 0,2600 & 0,1571 \\
\hline 27 & 0,1119 & 0,2905 & 0,2000 & 0,2600 & 0,2714 \\
\hline 28 & 0,1119 & 0,3286 & 0,2200 & 0,1400 & 0,3286 \\
\hline 29 & 0,1358 & 0,6333 & 0,3000 & 0,3000 & 0,3286 \\
\hline 30 & 0,1119 & 0,5190 & 0,2600 & 0,2200 & 0,2143 \\
\hline 31 & 0,1119 & 0,3667 & 0,3400 & 0,3000 & 0,2143 \\
\hline 32 & 0,1597 & 0,5190 & 0,2800 & 0,3000 & 0,4429 \\
\hline 33 & 0,1597 & 0,6333 & 0,6200 & 0,3400 & 0,4429 \\
\hline 34 & 0,2075 & 0,5190 & 0,5000 & 0,2600 & 0,2714 \\
\hline 35 & 0,2313 & 0,4429 & 0,4200 & 0,4200 & 0,1000 \\
\hline 36 & 0,2075 & 0,4048 & 0,3800 & 0,5000 & 0,2714 \\
\hline 37 & 0,2791 & 0,4429 & 0,4200 & 0,4600 & 0,2143 \\
\hline 38 & 0,3746 & 0,4429 & 0,4200 & 0,3000 & 0,2143 \\
\hline 39 & 0,4701 & 0,4810 & 0,4600 & 0,5400 & 0,4143 \\
\hline 40 & 0,6015 & 0,3667 & 0,3400 & 0,3800 & 0,4429 \\
\hline 41 & 0,6134 & 0,3286 & 0,3000 & 0,6600 & 0,5571 \\
\hline 42 & 0,4582 & 0,3667 & 0,3400 & 0,7800 & 0,7286 \\
\hline 43 & 0,5179 & 0,2333 & 0,2000 & 0,5800 & 0,8429 \\
\hline
\end{tabular}

Page : 33-48 


\begin{tabular}{cccccc}
\hline Minggu ke- & $\mathrm{x} 1(2014)$ & $\mathrm{x} 2(2015)$ & $\mathrm{x} 3(2016)$ & $\mathrm{x} 4(2017)$ & $\mathrm{T}(2018)$ \\
\hline $\mathbf{4 4}$ & 0,4224 & 0,9000 & 0,6800 & 0,6800 & 0,9000 \\
\hline $\mathbf{4 5}$ & 0,4463 & 0,6143 & 0,6000 & 0,8200 & 0,8429 \\
\hline $\mathbf{4 6}$ & 0,6134 & 0,3286 & 0,3000 & 0,6600 & 0,6143 \\
\hline $\mathbf{4 7}$ & 0,4701 & 0,4810 & 0,4600 & 0,5400 & 0,3857 \\
\hline $\mathbf{4 8}$ & 0,6134 & 0,3286 & 0,3000 & 0,6600 & 0,6143 \\
\hline $\mathbf{4 9}$ & 0,4701 & 0,4810 & 0,4600 & 0,5400 & 0,4143 \\
\hline $\mathbf{5 0}$ & 0,4701 & 0,4810 & 0,4600 & 0,5400 & 0,4143 \\
\hline $\mathbf{5 1}$ & 0,3746 & 0,4429 & 0,4200 & 0,3000 & 0,2714 \\
\hline $\mathbf{5 2}$ & 0,4701 & 0,4810 & 0,4600 & 0,5400 & 0,4143 \\
\hline $\mathbf{5 3}$ & 0,4701 & 0,4810 & 0,4600 & 0,5400 & 0,4143 \\
\hline
\end{tabular}

Page : 33-48

Tabel 7 Hasil Prediksi Jaringan Saraf Tiruan

\begin{tabular}{cccccccc}
\hline Bulan & $\begin{array}{c}\text { Minggu } \\
\text { ke- }\end{array}$ & Target & Output & Error & $\begin{array}{c}\text { Hasil } \\
\text { Prediksi }\end{array}$ & $\begin{array}{c}\text { Harga } \\
\text { Aktual }\end{array}$ & Selisih \\
\hline $\begin{array}{c}\text { Januari }, \\
\text { Februari } \\
\text { Maret }\end{array}$ & 1 & 0,8800 & 0,8808 & $-0,0008$ & 51328 & 52000 & -672 \\
\hline $\begin{array}{c}(2018) \\
\end{array}$ & 0,8000 & 0,8018 & $-0,0018$ & 48563 & 50000 & -1437 \\
\hline 3 & 0,8300 & 0,8333 & $-0,0033$ & 49666 & 51000 & -1335 \\
\hline 4 & 0,8000 & 0,8281 & $-0,0281$ & 49484 & 50000 & -517 \\
\hline 5 & 0,8000 & 0,8224 & $-0,0224$ & 49284 & 50000 & -716 \\
\hline 6 & 0,6400 & 0,6514 & 0,0114 & 43299 & 36000 & 7299 \\
\hline 7 & 0,6400 & 0,6499 & 0,0099 & 43194 & 36000 & 7194 \\
\hline 8 & 0,7700 & 0,7603 & 0,0087 & 48115 & 46000 & 2115 \\
\hline 9 & 0,7400 & 0,7365 & 0,0035 & 47678 & 44000 & 3678 \\
\hline 10 & 0,7700 & 0,7655 & 0,0045 & 48444 & 46000 & 2444 \\
\hline
\end{tabular}

Dari hasil perhitungan manual yang dilakukan pada 10 sampel data seperti yang dimuat pada tabel 4.20 terlihat bahwa terdapat selisih harga pada kisaran -1437 rupiah hingga 7299 rupiah. Selisih harga ini relatif baik sehingga memberikan indikasi bahwa metode backpropagation dengan arsitektur $4-8-1$ mampu melakukan prediksi harga cabe dengan baik.Perhitungan manual dilakukan pada 10 minggu awal pada tiap tahun input dan target yang berkisar pada bulan Januari hingga Maret. Dari hasil perhitungan didapat bahwa nilai keluaran berselisih tidak terlalu jauh dengan target harga aktual. Selisih tertinggi terjadi pada minggu keenam dimana terjadi perbedaan harga sebanyak 7299 rupiah. Sementara selisih terendah terjadi pada minggu keempat dimana terjadi perbedaan hanya pada -517 rupiah. rupiah.

\section{Hasil Pengujian}

Sebanyak 43 data harga cabe di Kota Payakumbuh akan digunakan dalam pelatihan JST dengan arsitektur 4-10-1. Data harga cabe mingguan tahun 2014,2015,2016, dan 2017 akan digunakan sebagai input, sementara data harga cabe mingguan pada tahun 2018 dijadikan sebagai target.

Proses implementasi dilakukan dengan menggunakan GUI untuk memudahkan pengguna dalam merubah parameter pelatihan. Tampilan GUI sistem prediksi cabe ditunjukkan pada gambar 


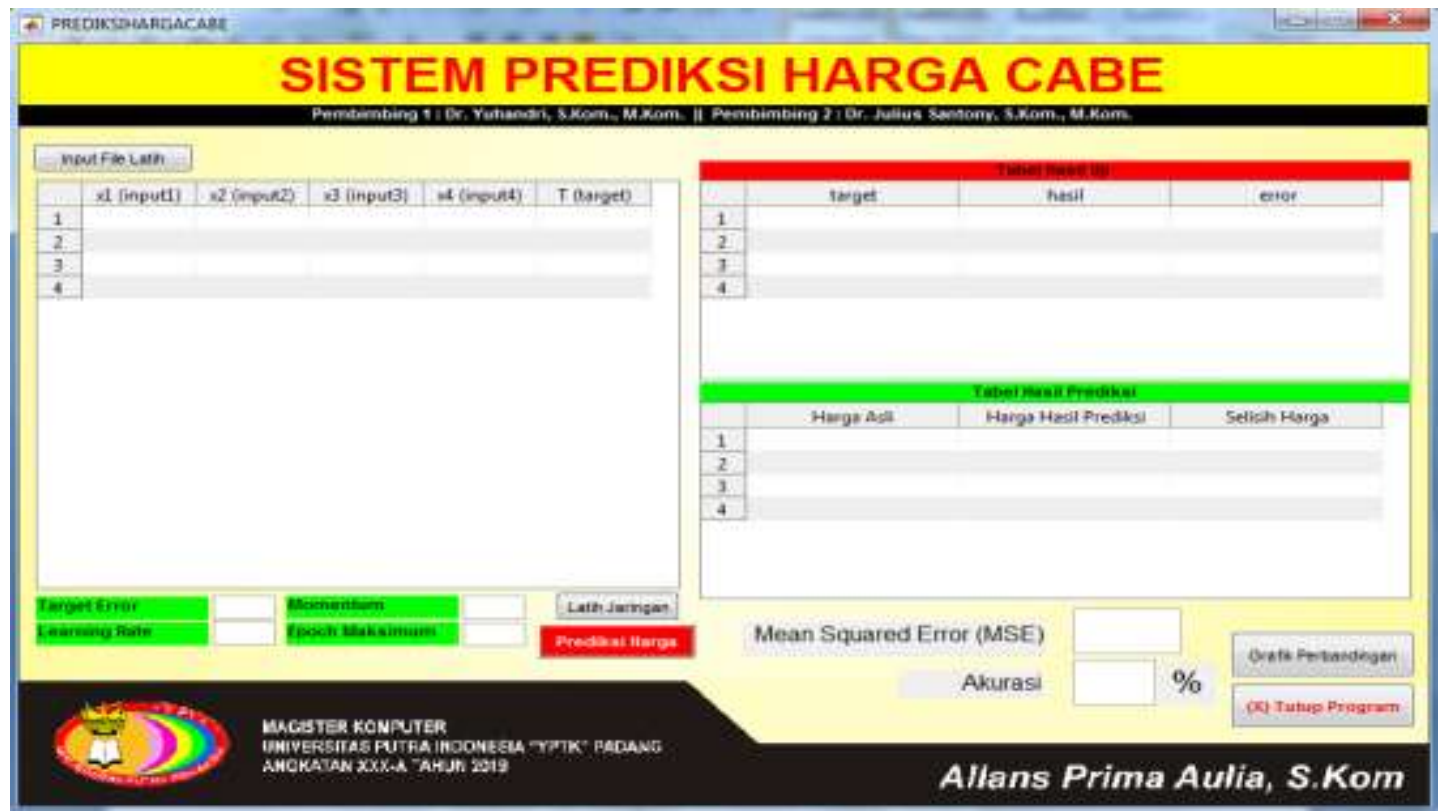

\section{Gambar 2 Tampilan GUI Sistem Prediksi Cabe}

1. Input Data

Pada tahap input data, dimasukkan data yang menjadi data pelatihan dengan menyusun 4 node input sesuai dengan arsitektur JST yang akan dibangun. Data telah disiapkan dalam bentuk database microsoft excel sesuai rancangan database pada Bab IV. Proses input data dilakukan dengan menekan tombol "Ambil Data Input" kemudian memilih file excel database input. Proses input data ditunjukkan pada gambar 5.3 berikut :

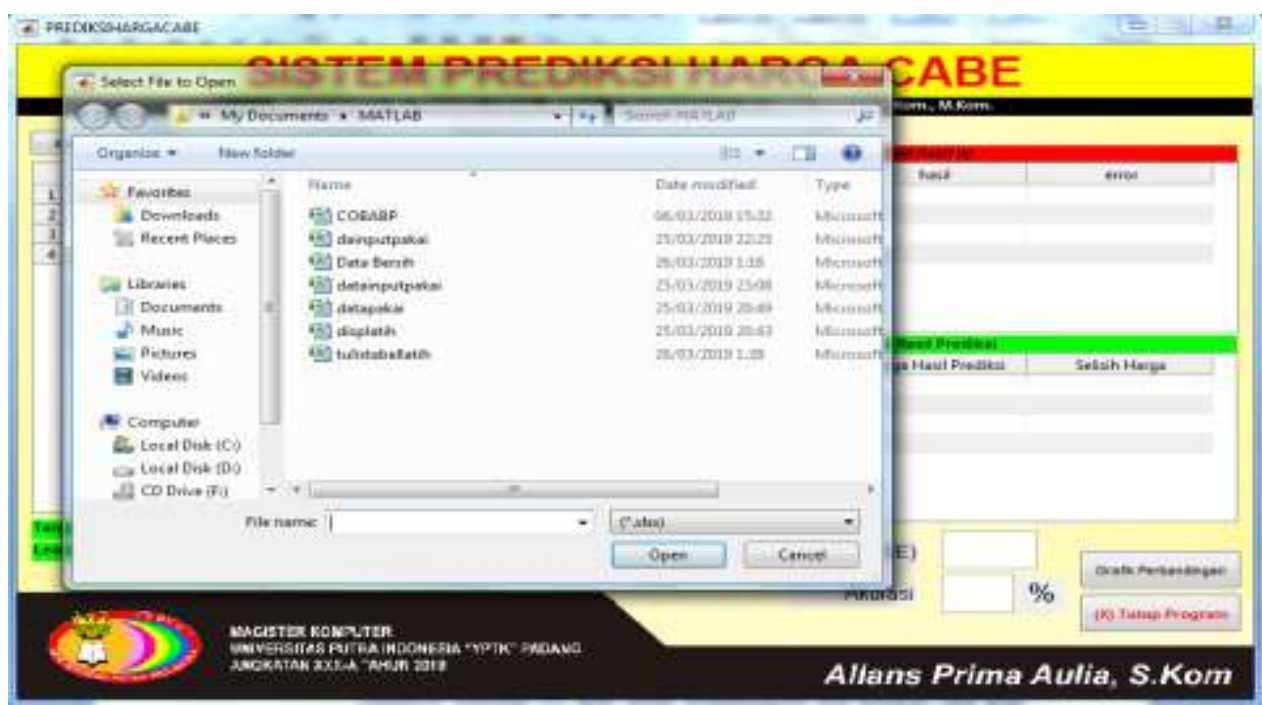

Gambar 3 Jendela Untuk Memilih File Input

Setelah file dipilih, selanjutnya nilai data yang terkandung dalam file tersebut akan ditampilkan pada display input data. File yang ditampilkan berupa file data yang telah ternormalisasi. Tampilan file input ditunjukkan pada gambar 5.4 berikut ini : 


\begin{tabular}{|c|c|c|c|c|c|}
\hline & $x 1$ (input1) & $\times 2$ (input2) & x3 (input3) & x4 (input4) & $\mathrm{T}$ (target) \\
\hline 1 & 0.4224 & 0.9000 & 0.6800 & 0.6800 & 0.9000 \\
\hline 2 & 0.4463 & 0.6143 & 0.6000 & 0.8200 & 0.8429 \\
\hline 3 & 0.4940 & 0.4238 & 0.3400 & 0.4600 & 0.8714 \\
\hline 4 & 0.2791 & 0.3286 & 0.3000 & 0.5000 & $0.8429 \equiv$ \\
\hline 5 & 0.4224 & 0.2905 & 0.3000 & 0.7000 & 0.8429 \\
\hline 6 & 0.3746 & 0.2905 & 0.3400 & 0.4800 & 0.4429 \\
\hline 7 & 0.3507 & 0.2524 & 0.5800 & 0.1800 & 0.4429 \\
\hline 8 & 0.2791 & 0.2905 & 0.5000 & 0.3000 & 0.7286 \\
\hline
\end{tabular}

\section{Gambar 4 File Input Yang Telah Diambil}

2. Membangun JST dengan Mengatur Parameter Pelatihan Parameter pelatihan JST akan sangat mempengaruhi nilai keluaran yang akan dihasilkan. Pemilihan parameter yang tepat tentu akan berimbas pada efisiensi JST dalam pelatihannya. Parameterparameter yang dapat diatur pada pelatihan jaringan antara lain adalah :

\section{a. Learning Rate}

Pada implementasi ini, learning rate diatur pada 0,1 dimana ini berarti tingkat pembelajaran pada tiap-tiap neuron berada pada nilai 0,1 . Perintah yang diketikkan pada command window untuk mengatur learning rate adalah :

net.trainParam.lr = 0.1;

b. Epoch Maksimum

Nilai epoch maksimum bermaksud untuk membatasi jumlah epoch yang akan dicapai dalam pelatihan jaringan. Ketika jumlah iterasi telah mencapai epoch maksimum, maka pelatihan akan berhenti. Karena data harga cabe di Kota Payakumbuh memiliki interval yang cukup tinggi, diberikan nilai epoch maksimum sebanyak 10.000. Maka perintah yang diketikkan pada command window adalah :

net.trainParam.epochs $=10000$;

c. Momentum

Pada pelatihan JST di tahap

implementasi ini, momentum yang

diatur adalah pada angka 0,95 .

Pengaturan momentum dilakukan

dengan mengetik kode berikut pada command window:

net.trainParam.mc $=0.95$;

d. Target Error

Target error merupakan toleransi

kesalahan atau merupakan tujuan yang akan dicapai dalam pelatihan JST. Pada implementasi sistem prediksi harga cabe diberikan target error sebesar 0,003. Artinya ketika pelatihan jaringan telah mencapai target tersebut, maka proses pelatihan akan dihentikan. Pada command window diketikkan perintah sebagai berikut : net.trainParam.goal $=0.003$;

e. Nilai Bobot dan Bias Awal Nilai bobot dan bias awal dapat diberikan secara acak maupun ditentukan oleh pengguna. Pemberian bobot secara acak akan mempermudah pengguna karena tidak perlu menentukan sendiri nilai tersebut, namun berdampak pada kinerja pelatihan yang cenderung inkonsisten. Maka dalam implementasi ini, nilai bobot dan bias awal ditentukan oleh pengguna dengan memasukkan perintah sebagai berikut :

net. $I W\{1,1\}=[10.1821551563556$,0.643329745328783 ,

4.34312325674330,12.93708760937 05 ;

$14.9938573896574,0.955917643739$ 111 ,

7.11595218510026,

8.16190321507567;

11.0698372412722,1.17253485441997,

11.5145665233200,21.5221472089190; 
11.8661186830363,-

12.9999113452704 ,

12.2245225689931,-

10.3381773051417;

$5.07723701762486,7.469833360092$

74 ,

$0.895515731477744,-$

11.8007245318748;

14.4346827941894, -

8.90396424642063 ,

$2.64136693977153,19.91412712149$

24 ;

12.3455135844832,-

2.53107102547695,

8.64389961188732,5.733591289251

55 ;

$4.34302085630378,3.504263861655$ 57 ,

1.9833809381536

4 ,-

1.5800770566247

4 ;

17.164301773928

6 ,

22.670513312551

8 ,

$10.2218775560666,3.908759190312$

22 ;

$3.84724961410343,8.759913325985$

26 ,

15.6322851316986];

$-4.14510720912046,-$

net. $L W\{2,1\}=[$ -

8.61597193680409,5.166946057969

89 ,

$7.66324052405182,0.607207596440$

144 ,
Jurnal KomtekInfo , Vol.8 No.1 Tahun 2021

e-ISSN : 2502-8758 || p-ISSN : 2356-0010 DOI : $10.35134 /$ komtekinfo.v7i4

Page : 33-48

4.76175767611783,4.993296902414 04 ,

$3.23641029596889,9.078347440748$ 59 ,

1.87457036820413];

$-1.64031615778778,-$

net.b $\{1,1\}=[-9.44701058710590$; 4.21413678789837;

11.9339382701901;-

0.704063580006427

$9.63416461172882 ; 4.45886311001$ 659;

$6.73360003786675 ; 2.56036997790$ 331;

7.75880221861162;8.30715199695 743];

net. $b\{2,1\}=-2.37582431047618$;

f. Mengatur Fungsi Pelatihan

Pada pelatihan JST, fungsi pelatihan menjadi salah satu parameter yang akan mempengaruhi hasil pelatihan jaringan. Pada tahap implementasi ini, fungsi pelatihan yang digunakan adalah traingdx. Perintah yang diketikkan pada command window adalah :

net $=$ newff(minmax $($ data_latih $),[10$ 1],\{'logsig','purelin'\},'traingdx');

g. Mengatur Fungsi Aktivasi Pada tahap implementasi ini, fungsi aktivasi yang digunakan adalah logsig pada hidden layer, dan purelin pada output layer. Setelah semua parameter diatur, pelatihan JST siap dilakukan.

Proses pengaturan yang dapat dilakukan pada GUI sistem prediksi cabe ditunjukkan pada gambar 5.5 berikut ini :

\begin{tabular}{|l|c|}
\hline Target Error & 0.0033 \\
\hline Learning Rate & 0.1 \\
\hline
\end{tabular}

\begin{tabular}{|l|c|}
\hline Momentum & 0.95 \\
\hline Epoch Maksimum & 1000 \\
\hline
\end{tabular}




\section{Gambar 5 Pengaturan Parameter Pelatihan JST}

3. Memulai Pelatihan JST

Pelatihan jaringan ini akan dimulai ketika pengguna menekan button "Latih Jaringan" dengan menggunakan nilainilai parameter yang telah diatur sebelumnya. Dari parameter-parameter di atas, pelatihan berhenti pada epoch Maksimum yaitu iterasi ke 1.000 dengan kondisi target error belum sepenuhnya tercapai. Proses pelatihan jaringan ditunjukkan pada gambar 5.6 berikut ini

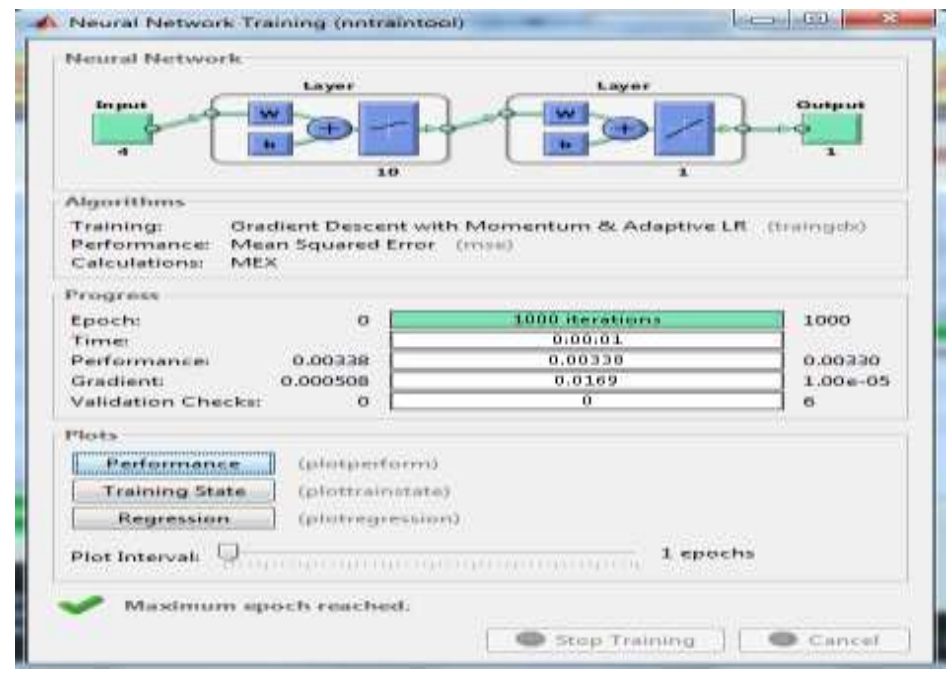

Gambar 6 Proses Pelatihan JST

Setelah proses pelatihan dengan 1000 epochs dilakukan, diperoleh nilai MSE sebesar 0,00338 . Nilai ini sudah cukup baik dan akan menghasilkan nilai prediksi yang akurat.
Selanjutnya nilai yang didapat dari hasil pelatihan akan ditampilkan pada "display hasil pelatihan" seperti ditunjukkan pada gambar 5.7 :

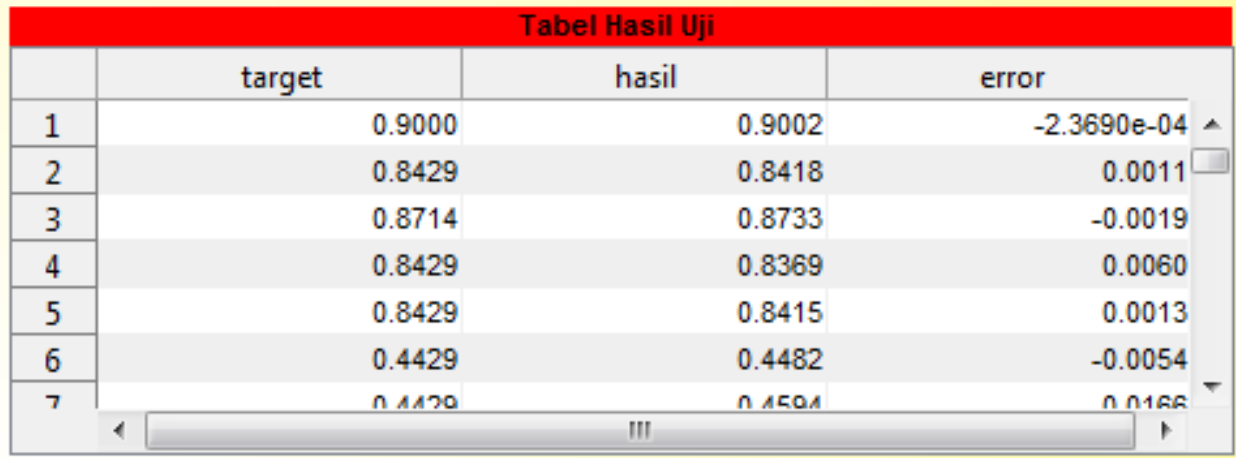

Gambar 7 Tabel Hasil Pelatihan JST dengan Epochs 1000

Setelah melewati proses pelatihan jaringan, selanjutnya dilakukan proses pengujian atau proses memprediksi harga cabe. Proses ini akan dimulai ketika pengguna menekan tombol
"Prediksi Harga". Hasil prediksi harga akan ditampilkan pada "Display Hasil Prediksi" seperti yang ditunjukkan pada gambar 8 berikut ini : 


\begin{tabular}{|c|c|c|c|c|c|}
\hline \multicolumn{6}{|c|}{ Tabel Hasil Prediksi } \\
\hline & & Harga Asli & Harga Hasil Prediksi & Selisih Harga & \\
\hline 1 & & 52000 & $5.2013 \mathrm{e}+04$ & -13.3708 & A \\
\hline 2 & & 50000 & $4.9965 e+04$ & 35.3250 & \\
\hline 3 & & 42000 & $4.0013 e+04$ & $1.9873 e+03$ & $\equiv$ \\
\hline 4 & & 34000 & $3.4955 e+04$ & -954.7616 & \\
\hline 5 & & 42000 & $4.0013 e+04$ & $1.9873 e+03$ & \\
\hline 6 & & 35000 & $3.4955 e+04$ & 45.2384 & \\
\hline$\rightarrow$ & 1 & arnan & III Anrr..ns & armas & \\
\hline
\end{tabular}
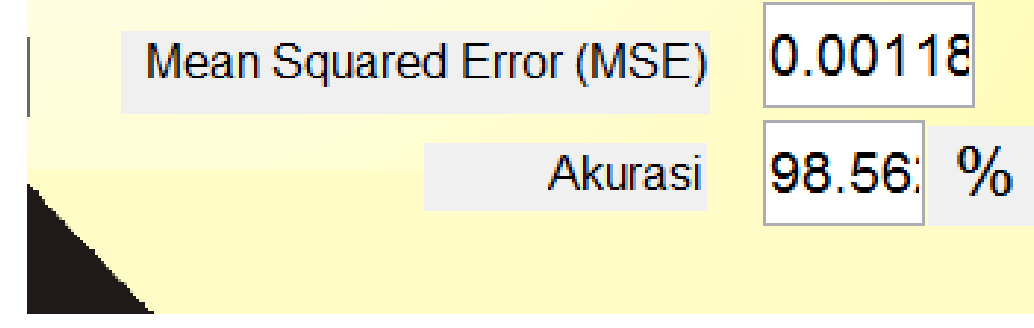

\section{Grafik Perbandingan}

(X) Tutup Program

\section{Gambar 8 Display Hasil Prediksi}

Pada "Display Hasil Prediksi" ditampilkan data hasil prediksi dengan presisi data hingga 15 digit dibelakang koma. Nilai ini merupakan nilai default pada Matlab R2015b. Selain ditampilkan pada "Display Hasil Prediksi", hasil prediksi juga diexport ke dalam database excel untuk mempermudah mempelajari hasil.

Dari implementasi yang telah dilakukan dengan menggunakan GUI pada Matlab R2015b, diperoleh hasil pengujian berupa harga cabe aktual, harga hasil prediksi, selisih harga, nilai $M S E$, dan akurasi prediksi. Data harga aktual, data hasil prediksi, dan selisih harga dimuat pada tabel 9 berikut :

Tabel 8 Hasil Prediksi Cabe Menggunakan Metode Backpropagation

\begin{tabular}{ccc}
\hline DATA ASLI & $\begin{array}{c}\text { HASIL } \\
\text { PREDIKSI }\end{array}$ & SELISIH \\
\hline $\mathbf{5 2 0 0 0}$ & 52013 & 13 \\
\hline $\mathbf{5 0 0 0 0}$ & 49964 & -36 \\
\hline $\mathbf{4 2 0 0 0}$ & 40012 & -1988 \\
\hline $\mathbf{3 4 0 0 0}$ & 34954 & 954 \\
\hline $\mathbf{4 2 0 0 0}$ & 40012 & -1988 \\
\hline $\mathbf{3 5 0 0 0}$ & 34954 & -46 \\
\hline $\mathbf{3 5 0 0 0}$ & 34954 & -46 \\
\hline $\mathbf{3 0 0 0 0}$ & 27617 & -2383 \\
\hline $\mathbf{3 5 0 0 0}$ & 34954 & -46 \\
\hline
\end{tabular}

LPPM Universitas Putra Indonesia YPTK Padang

$\begin{array}{lll}35000 & 34954 & -46\end{array}$

Pada tabel di atas terlihat bahwa selisih harga terendah terjadi pada data uji pertama, yaitu 13 Rupiah, sedangkan selisih harga tertinggi terjadi pada data uji ketujuh dengan nilai -2383 Rupiah. Untuk mendapatkan nilai akurasi dilakukan dengan melakukan pembagian pada seluruh jumlah hasil prediksi dengan jumlah data asli, kemudian dikalikan $100 \%$. Atau dapat dituliskan dengan rumus berikut :

Akurasi $=(($ SUM $[$ Hasil Prediksi $]) /($ SUM $[$ Data Asli] )) x $100 \%$

Dari proses perhitungan di atas, diperoleh bahwa nilai akurasi dari sistem prediksi cabe ini adalah $98,56 \%$. Tingkat akurasi ini sangat baik dan membuktikan bahwa metode backpropagation cocok digunakan untuk melakukan peramalan.

\section{KESIMPULAN}

Dari penelitian yang telah dilakukan diketahui bahwa metode backpropagation terbukti mampu melakukan prediksi harga cabe dengan akurasi yang baik. Karenanya, sebagai rangkuman dari penelitian ini, ditarik beberapa kesimpulan hasil dari penelitian. Kesimpulan yang didapat dari penelitian ini diantaranya adalah metode backpropagation yang digunakan pada sistem prediksi harga cabe berdasarkan data harga dari BPS Kota Payakumbuh mampu memberikan hasil prediksi yang akurat,p roses 
perhitungan propagasi balik pada metode backpropagation dapat dilakukan dengan cepat dan tepat ketika diterapkan pada software Matlab sehingga menghasilkan akurasi yang baik sebesar 98,56 \%. Graphic User Interface (GUI) yang dirancang pada sistem prediksi harga cabe dapat dimanfaatkan oleh masyarakat umum untuk memperoleh informasi prediksi harga cabe dengan akurasi yang baik.

\section{REFERENSI}

Lesnussa, Y. A., Sinay, L. J. and Idah, M. R. (2017) 'Aplikasi Jaringan Saraf Tiruan Backpropagation untuk Penyebaran Penyakit Demam Berdarah Dengue (DBD) di Kota Ambon', Jurnal Matematika Integratif, 13(2), p 63. doi: 10.24198/jmi.v13.n2.11811.63-72. Nur Hudha Wijaya, Indah Soesanti, E. F. (2017) 'Klasifikasi Suara Jantung Menggunakan Neural
Jurnal KomtekInfo, Vol.8 No.1 Tahun 2021

e-ISSN : $\underline{2502-8758}$ || p-ISSN : 2356-0010 DOI : $10.35134 /$ komtekinfo.v7i4

Page : 33-48

Network Backpropagation Berbasis Ciri Statitis', pp. 89-96.

Pamungkas, W. W. et al. (2018) 'Pemodelan Statistical Control Detection Adaptive (SCDA) Untuk Monitoring Dan Prediksi Volume Produksi Crude Palm Oil (CPO) Nasional', Jurnal Teknologi Industri Pertanian, 27(1), pp. 1-8. Peole, I. N., Ratianingsih, R. and Lusiyanti, D. (2018) 'Mengkaji Perilaku Harga Komoditi Pangan Di Kota Palu Menggunakan Metode Backpropagation', Jurnal Ilmiah Matematika Dan Terapan, 15(1), pp. 58-68. doi: 10.22487/2540766x.2018.v15.11.10199.

Pujianto, A., Kusrini, K. and Sunyoto, A. (2018)

'Perancangan Sistem Pendukung Keputusan Untuk Prediksi Penerima Beasiswa Menggunakan Metode Neural Network Backpropagation', Jurnal Teknologi Informasi dan Ilmu Komputer, 5(2), p. 157. doi: 10.25126/jtiik.201852631. 